\title{
Article \\ Effect of Irrigation on Intercropping Systems of Wheat (Triticum aestivum L.) with Pea (Pisum sativum L.)
}

\author{
Chrysanthi Pankou ${ }^{1}$ (D) Anastasios Lithourgidis ${ }^{2}$ and Christos Dordas ${ }^{1, *(D)}$ \\ 1 Laboratory of Agronomy, School of Agriculture, Aristotle University of Thessaloniki, \\ 54124 Thessaloniki, Greece; cpankou@gmail.com \\ 2 Farm of Aristotle University of Thessaloniki, 57001 Thermi, Greece; lithour@auth.gr \\ * Correspondence: chdordas@agro.auth.gr; Tel.: +30-2310-998-602; Fax: +30-2310-998-634
}

Citation: Pankou, C.; Lithourgidis, A.; Dordas, C. Effect of Irrigation on Intercropping Systems of Wheat (Triticum aestivum L.) with Pea (Pisum sativum L.). Agronomy 2021, 11, 283. https://doi.org/10.3390/ agronomy11020283

Academic Editor:

Carlos Cantero-Martínez

Received: 24 December 2020

Accepted: 30 January 2021

Published: 3 February 2021

Publisher's Note: MDPI stays neutral with regard to jurisdictional claims in published maps and institutional affiliations.

Copyright: (c) 2021 by the authors. Licensee MDPI, Basel, Switzerland. This article is an open access article distributed under the terms and conditions of the Creative Commons Attribution (CC BY) license (https:// creativecommons.org/licenses/by/ $4.0 /)$.

\begin{abstract}
Intercropping is an old and commonly used agricultural practice and involves the cultivation of two or more crops in the same area of land at the same time and may improve yield, the use of the environmental resources, product quality, and soil health. The objective of the present study was to study the effect of water availability of wheat-pea intercrops using agronomic and physiological characteristics. The experiment was conducted at the farm of Aristotle University of Thessaloniki, Greece during two growing seasons 2017-2018 and 2018-2019 using two different cultivars from pea (Isard and Olympos) and wheat (Yecora E and Elissavet) and two irrigation regimes. The availability of water increased grain yield and affected most of the characteristics that were studied. In terms of total Land Equivalent Ratio (LER) there was a yield advantage of intercrops over monocrops, which indicates the efficiency of intercropping for using the environmental resources. Both wheat cultivars, the pea cultivar Olympos and their intercrops indicated high adaptation capacity to rainfed conditions, whereas Isard and its intercrops performed better under irrigation. Therefore, the intercropping of wheat with pea uses the water resources of the environment more efficiently and can be used in dry land conditions for higher yield.
\end{abstract}

Keywords: grain yield; yield components; land equivalent ratio; mixture; cultivar

\section{Introduction}

Over the last decade, there has been considerable interest in the low-input agricultural systems across the world and especially in Europe. This is because modern agriculture with the extensive use of agrochemicals, monocultures, and mechanization led to oversimplification of the agricultural systems and to a significant loss of biodiversity. Therefore, it is important to increase the farm biodiversity through agricultural practices that promote the ecosystem services and maintain soil fertility, controlling pests and promote sustainability. The farm biodiversity can be increased using crop rotation, cover crops, intercropping, and agroforestry [1,2].

Intercropping is a system where two or more crops species or genotypes are grown at the same space and the same time [3-6]. Further, the different component crops of an intercropping system do not necessarily have to be sown at the same time nor they have to be harvested at the same time, but they should be grown simultaneously for a great part of their growth periods. The plant species in an intercropping system normally are from different families and is less common when they are different genotypes of the same crop species. The main advantages of intercropping are higher yield and stability of yield, better environmental resources utilization, insurance against crop failure, soil conservation, improvement of soil fertility, improvement of forage quality, lodging resistance to prone crops, reduction of pest, and disease incidence and promotion of biodiversity. However, there are significant disadvantages of intercropping such as competition for light, water, and nutrients or allelopathic effects, the difficulty for practical management and the 
mechanization since the management practices were developed for only one species per field $[3,4,6]$.

Intercropping is a system that promotes ecological intensification as it increases biodiversity in cropping systems by increasing the number of cultivated species and especially by increasing the proportion of legumes in cropping systems. The interactions that exists between species in intercropping systems are quite complex and were proposed that can be explained by the "four Cs" principles Competition, Complementarity, Cooperation, and Compensation [7]. Competition exists for resources such as water, light, and nutrients etc. [7]. The next principle is complementarity in which the mixtures use the environmental resources more efficient compared with sole cropping [7]. The third principle is cooperation, which happens through facilitation in which there is a modification of the environment by one species and this is beneficial to the other(s) [7]. Finally, compensation is the principle were the species in the mixture differ in their sensitivity to abiotic and/or biotic stress and when one is demised is compensated by the other(s) through release from competition. An efficient intercropping system is one that provides higher total yield by utilizing more efficiently the environmental resources than the sole crop system [8]. In order to find the most efficient intercropping system it is important to take into account the four Cs principles and utilize them [7].

Water stress is very important for agricultural crops and affects the yield and product quality in many areas and especially in the Mediterranean region. Moreover, climate change will affect water availability and will be a limiting factor for many countries the following years. Therefore, it is important to use water resources more efficiently which will help us to preserve the valuable water resources. One of the ways to conserve water is by using the appropriate cropping system and also appropriate crop species and cultivars, which have low requirements for water [9]. A cropping system that has been reported that increases soil water conservation is intercropping [9-11]. In addition, intercropping reduces run-off, can increase the use of available soil water, increased crop yield for the entire systems and the yield per unit of water applied, and the yield of crops grown the following year in the rotation. Furthermore, it was reported that intercropping in arid and semiarid areas can increase water use efficiency (WUE) significantly [11,12]. However, it was not studied how the different cultivars can contribute to WUE.

There is not enough information about how intercropping can affect the WUE and whether the use of different cultivars can increase WUE. Therefore, the objective of the present study was to determine (1) the effect of water availability on intercropping systems under rainfed conditions, (2) how the different cultivars respond to intercropping systems and to difference in water availability, and (3) to assess the impact of the intercropping system on the component species under different water levels.

\section{Materials and Methods}

\subsection{Experimental Site}

The experiments were conducted for two successive growing seasons (2017-2018 and 2018-2019) at the Farm of Aristotle University of Thessaloniki at the area of Thermi $\left(40^{\circ} 32^{\prime} 9^{\prime \prime} \mathrm{N} 22^{\circ} 59^{\prime} 18^{\prime \prime} \mathrm{E}, 0 \mathrm{~m}\right)$. The soil type was a clay loam with organic matter $10 \mathrm{~g} \mathrm{~kg}^{-1}$, $\mathrm{pH}\left(1: 1 \mathrm{H}_{2} \mathrm{O}\right) 8.1$, electrical conductivity $\left(\mathrm{dS} \mathrm{m}^{-1}\right) 0.621$, and $\mathrm{CaCO}_{3} 5 \%$. Weather conditions were recorded daily with an automatic weather station, which was close to the experimental site and were reported as mean monthly data for both years (Table 1). Both years showed small differences regarding the weather conditions (Table 1). 
Table 1. The main weather parameters (mean temperature, rainfall, and reference evapotranspiration $\mathrm{ET}_{\mathrm{O}}$ ) for the two growing seasons 2017-2018 and 2018-2019 of experimentation at Thermi Greece and its comparison to the 30-year average. The weather data were recorded with an automatic weather station close to the experimental site.

\begin{tabular}{lccccccccc}
\hline Month & \multicolumn{3}{c}{ Rainfall $(\mathbf{m m})$} & \multicolumn{3}{c}{ Temperature $\left.{ }^{\circ} \mathbf{C}\right)$} & \multicolumn{3}{c}{ ET $_{\mathbf{o}}(\mathbf{m m} / \mathbf{M o n t h})$} \\
\hline & $\mathbf{2 0 1 7}$ & $\mathbf{2 0 1 8}$ & $\begin{array}{c}\mathbf{3 0} \\
\text { Years }\end{array}$ & $\mathbf{2 0 1 7}$ & $\mathbf{2 0 1 8}$ & $\begin{array}{c}\mathbf{3 0} \\
\text { Years }\end{array}$ & $\mathbf{2 0 1 7}$ & $\mathbf{2 0 1 8}$ & $\begin{array}{c}\mathbf{3 0} \\
\text { Years }\end{array}$ \\
\hline December & 26.0 & 36.0 & 50.8 & 9.3 & 6.4 & 6.5 & 44.6 & 23.7 & 28.1 \\
January & 14.2 & 44.8 & 29.3 & 7.1 & 6.1 & 5.2 & 34.1 & 18.7 & 20.3 \\
February & 69.6 & 8.4 & 31.5 & 9.1 & 7.9 & 6.4 & 50.0 & 23.7 & 35.8 \\
March & 49.8 & 14.6 & 31.5 & 13.0 & 12.0 & 9.6 & 72.4 & 62.1 & 65.4 \\
April & 70.0 & 71.4 & 38.2 & 18.9 & 14.5 & 13.9 & 102.3 & 95.2 & 98.3 \\
May & 25.2 & 23.0 & 44.4 & 23.3 & 19.5 & 19.3 & 177.3 & 139.5 & 152.4 \\
June & 87.0 & 52.0 & 32.4 & 24.6 & 26.7 & 24.5 & 209.7 & 148.9 & 181.7 \\
\hline
\end{tabular}

\subsection{Genotypes Used in the Study}

Two wheat (Triticum aestivum L.) and two pea (Pisum sativum L.) cultivars as well as their mixtures of each wheat cultivar with each pea cultivar were used in this study. The wheat cultivars that were used were Yecora E and Elissavet which were different in earliness and in plant height as Elissavet was taller than Yecora E. In addition, two different pea cultivars were used Isard which is an afila type and Olympos fully leaf.

\subsection{Crop Management and Experimental Design}

Pea and wheat monocrops, as well as mixtures of pea cultivars with each of the wheat cultivar were sown on the first week of December in both growing seasons. The seeding ratio was 75:25 (pea:wheat) based on seed weight. The seeding rates for pea and wheat monocrops were 130 and $150 \mathrm{~kg} \mathrm{ha}^{-1}$ respectively, whereas the seeding rates for intercrops were 98 and $38 \mathrm{~kg} \mathrm{ha}^{-1}$ (pea-wheat). Seeds of both species were sown simultaneously. The seeding ratio was selected as it was found from previous experiments in the area [13-15].

The previous crop was barley (Hordeum vulgare L.) and after harvest, the straw was baled and removed. The tillage system that was used was the conventional and the soil was moldboard plowed, harrowed and a cultivator was used. All crops were kept free of weeds by implementing hand hoeing, where necessary.

The experimental design was a Randomized Complete Block Design (RCBD) in a split-split plot arrangement, where irrigation levels were the main plots, monocrops and mixtures were the sub-plots. In addition, we used four replications (blocks) per treatment combination, each block was divided in two strips, which were the two irrigation, and within each strip the four monocrops and four mixtures were randomized. Every experimental plot was $4 \mathrm{~m}$ in length and $1.25 \mathrm{~m}$ in width with five rows $25 \mathrm{~cm}$ apart and the total size of each plot was $5 \mathrm{~m}^{2}$. The plots were separated by a $1.25 \mathrm{~m}$ buffer zone.

Two irrigation treatments were used one with no irrigation (rainfed) and all the water that was needed the crop received it from the rainfall and the other where the crop evapotranspiration was calculated and provided to cover the plant needs as it was described before [16]. The water was applied with a drip irrigation system with the drippers spaced at $50 \mathrm{~cm}$ intervals the water supply of the drippers was $4 \mathrm{~L} \mathrm{~h}^{-1}$. The drip irrigation lines were placed every other row. The same irrigation system was extensively used in other experiments [16]. Reference evapotranspiration $\left(\mathrm{ET}_{\mathrm{O}}\right)$ was calculated with the FAO Penman-Monteith method as described before [16].

\subsection{Grain Yield Determination}

In order to determine the grain yield all the plants from the three central rows were cut at ground level manually and the grains were received with a LD 350 laboratory thresher (Wintersteiger, AG, Ried im Innkreis, Austria) in the first week of June in both years. Following the grains were separated for the intercropping treatments with a grain separator. 


\subsection{Seed Yield Components}

The yield components (number of spikes per plant, number of pods per plant, number of grains per spike, number of grains per pod, length of spike, and length of pod) were determined by measuring the number of spikes, pods, and seeds from 20 plants per plot at harvest when the plants had already reached physiological maturity.

\subsection{Chlorophyll Fluorescence and Chlorophyll Content}

The minimum $\mathrm{Chl}$ fluorescence $\left(\mathrm{F}_{0}\right)$ and the maximum $\mathrm{Chl}$ fluorescence $\left(\mathrm{F}_{\mathrm{m}}\right)$ were measured also in situ with the portable Z995 FluorPen PAR (Qubit Biology Inc. Kingston, Ontario, Canada). For each plot 10 young fully expanded leaves were used before each sampling. The maximum quantum efficiency of photosystem (PS) II was calculated as $\mathrm{F}_{\mathrm{v}} / \mathrm{F}_{\mathrm{m}}\left(\mathrm{F}_{\mathrm{v}}=\mathrm{F}_{\mathrm{m}}-\mathrm{F}_{0}\right)$ (Zadoks growth stage 60) and full bloom for pea.

Chlorophyll content readings (SPAD units) were taken with a hand-held dual-wavelength meter (SPAD 502 Plus, Chlorophyll meter, Konica Minolta Optics Inc., Osaka, Japan). For each plot 10 young fully expanded leaves were used before each sampling. The instrument stored and automatically averaged these readings to generate one reading per plot (Zadoks growth stage 60) and full bloom for pea.

\subsection{Water Use Efficiency}

The WUE for the different treatments was determined by dividing the dry weight yield by the total water (rainfall and irrigation) that each treatment received [17].

\subsection{Land Equivalent Ratio (LER)}

The advantage of intercropping and the effect of competition between the two species used in a mixture was calculated using the land equivalent ratio (LER). In particular, LER indicates the efficiency of intercropping for using the environmental resources compared with monocropping. The value of unity is considered the critical value for this index. When LER is greater than one the intercropping favors the growth and yield of the intercropped species, whereas when LER is lower than one the intercropping negatively affects the growth and yield of the species $[18,19]$. The LER was calculated as

$$
\begin{gathered}
\mathrm{LER}=\left(\mathrm{LER}_{\mathrm{p}}+\mathrm{LER}_{\mathrm{w}}\right), \\
\mathrm{LER}_{\mathrm{p}}=\left(\mathrm{Y}_{\mathrm{pi}} / \mathrm{Y}_{\mathrm{p}}\right), \\
\mathrm{LER}_{\mathrm{w}}=\left(\mathrm{Y}_{\mathrm{wi}} / \mathrm{Y}_{\mathrm{w}}\right),
\end{gathered}
$$

where $Y_{p}$ and $Y_{w}$ are the yields of pea and wheat, respectively, as monocrops and $Y_{p i}$ and $\mathrm{Y}_{\mathrm{wi}}$ are the yields of pea and wheat, respectively, as intercrops.

\subsection{Statistical Analysis}

All data (grain yield, yield components, chlorophyll content, chlorophyll fluorescence, LER and WUE) were analyzed within the methodological frame of Mixed Linear Models with the Analysis of Variance (ANOVA) method according to the model that involves the effects (main and interactions) of three factors: 2 "growing seasons" $\times 2$ "irrigation levels" $\times 8$ "intercropping treatments". The experiment was installed according to the Randomized Complete Block Design (RCBD) in a split-split-plot arrangement, utilizing data from four blocks per combined treatment. The "growing seasons" were considered as the main plots, "irrigation levels" were considered as the sub-plots, "intercropping treatments" were considered as the sub-sub-plots [20]. Within each growing season the basic experimental design was the RCBD in a split plot arrangement: "irrigation levels" were the main plots, and "intercropping treatments" were the sub-plots. Following, pairwise differences between treatments' means were tested with the protected Least Significant Difference (LSD) criterion. The significance level of all hypothesis testing procedures was preset at $\mathrm{a}=0.05(p \leq 0.05)$. For all parameters, the variances were not statistically different 
between the growing seasons and a common LSD value (for both years) was calculated and used for mean comparisons. Since no statistically significant interaction between growing seasons and treatments was detected the mean values for both growing seasons are presented. The SPSS software (IBM SPSS Statistics 25, IBM Corp. Released 2017, Armonk, NY, USA) was used for the statistical analyzes.

\section{Results}

\subsection{Grain Yield}

The statistical analysis of the grain yield and the other characteristics that were studied showed that there was no treatment by growing season interaction, so the treatment means are presented averaged across growing seasons.

Under irrigated conditions, there were significant differences in grain yield among treatments (Figure 1). In particular, the mixture Isard-Yecora E had the highest grain yield (5.22 tn ha $\left.{ }^{-1}\right)$, followed by the mixture of Isard-Elissavet (4.89 tn ha $\left.{ }^{-1}\right)$, and the monocrops of both wheat cultivars. Among the pea monocrops, Isard had the highest grain yield, while both wheat cultivars had similar grain yields. On the other hand, Olympos and its mixtures with each of wheat cultivars have the lowest yields. Under water stress conditions, the highest grain yield was found at the wheat monocrops and followed by the Elissavet-Isard mixture.

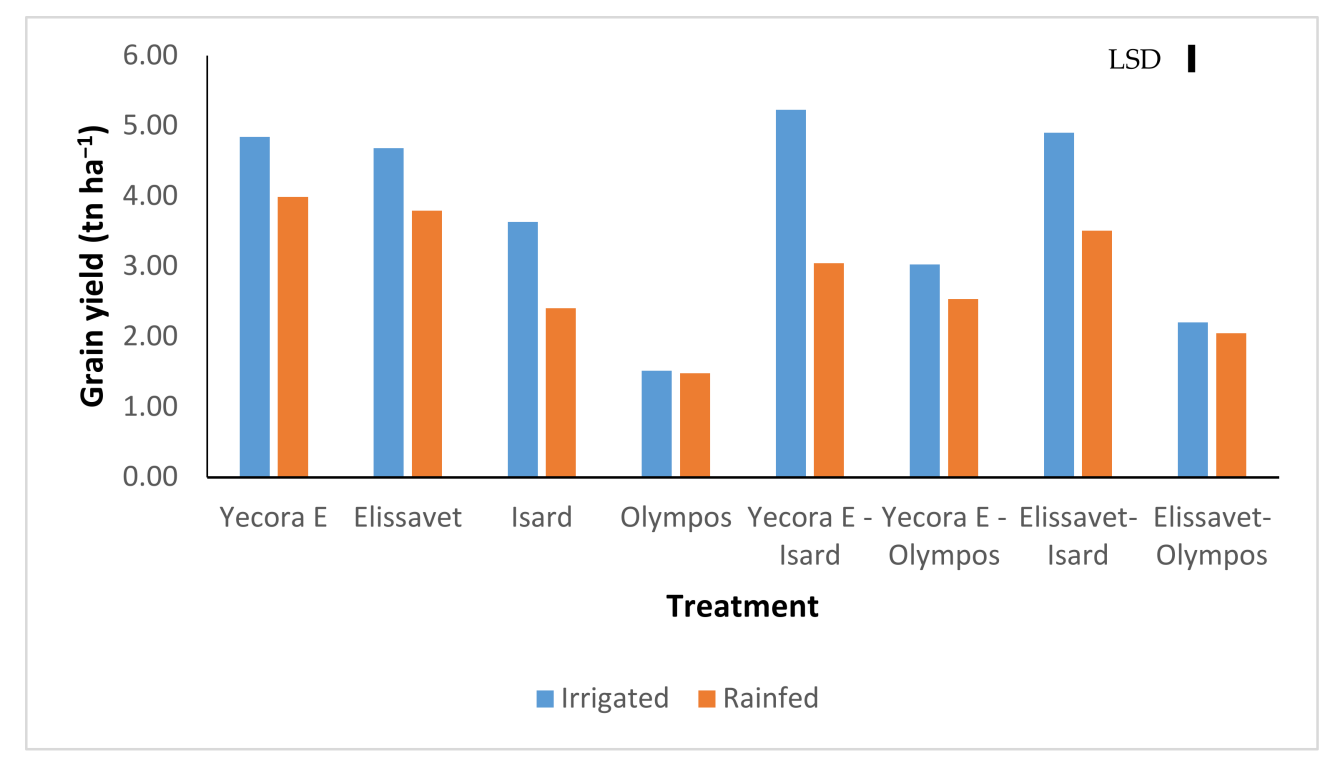

Figure 1. Grain yield of monocrops of wheat and pea and their intercrops that were used under Rainfed and Irrigated conditions. Data presented are mean values; vertical bar corresponds to the least significant difference (LSD).

The monocrop of the pea cultivar Isard was significantly affected by the irrigation treatments as the grain yield was reduced by $34 \%$ under water stress conditions compared with the irrigated treatment (Figure 1). Similarly, both mixtures of Isard, e.g., Yecora E-Isard and Elissavet-Isard were yielded lower by 42 and $28 \%$, respectively, under water stress compared with the irrigation. In contrast, Olympos monocrop, as well as the mixtures of Olympos with both wheat cultivars were not affected by the water stress conditions, as the reduction of grain yield was not statistically significant.

\subsection{Yield Components}

Most of the yield components were affected by irrigation and also by the intercropping treatments (Figures 2 and 3, Table 2). In particular, there was a 34, 39, and 43\% increase on the number of spikes per plant with irrigation in the Yecora E-Olympos, Yecora E-Isard, and Elissavet-Isard mixtures, respectively, compared with the rainfed conditions, whereas at the both wheat monocrops and the Elissavet-Olympos mixture there was no effect on 
the number of spikes per plant (Figure 2). Similar trend to that of the number of spikes per plant was also observed for the number of grains per spike (Table 1). In particular, there was increase in irrigated treatments of the number of grains per spike by 20, 20, and 31\% at the Yecora E-Olympos, Elissavet-Isard, and Yecora E-Isard mixtures, respectively. On the contrary, wheat monocrops and the Elissavet-Olympos intercrop were not significantly affected under irrigation conditions. Further, the length of spikes was not significantly affected by the irrigation treatment.

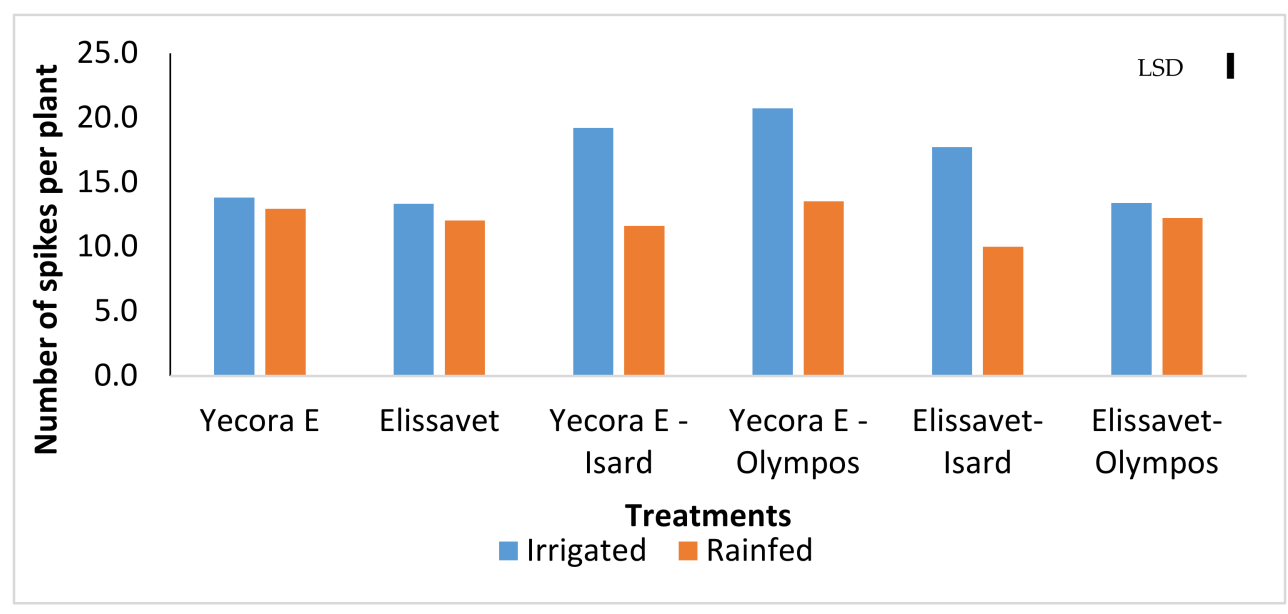

Figure 2. Number of spikes per plant of monocrops of wheat its intercrops that were used under Rainfed and Irrigated conditions. Data presented are mean values; vertical bar corresponds to the least significant difference (LSD).

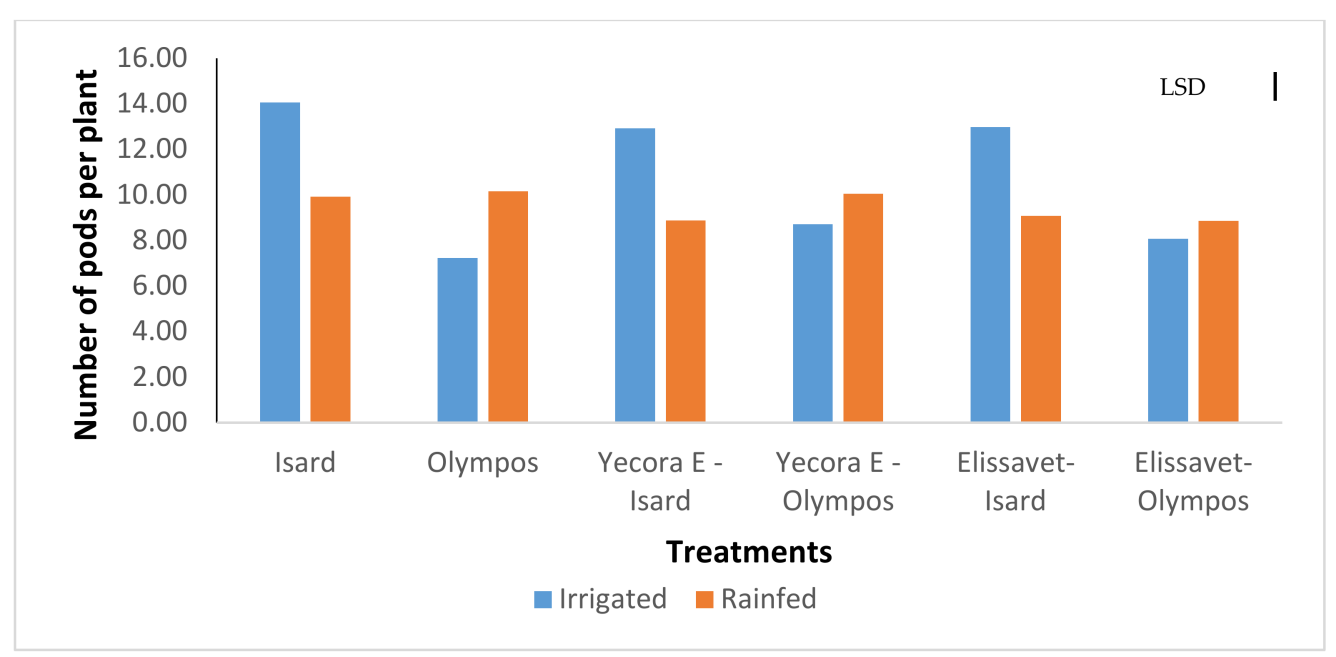

Figure 3. Number of pods per plant of monocrops of pea and its intercrops that there were used under Rainfed and Irrigated conditions. Data presented are mean values; vertical bar corresponds to the least significant difference (LSD).

The number of pods per plant was also affected by the irrigation treatment and also by the mixtures (Figure 3). Isard showed a significant increase with irrigation in monocrops and its intercrops, as it was 29,30, and 31\% at the monocrop, Elissavet-Isard and Yecora E-Isard intercrops, respectively. In contrast the number of pods for Olympos was reduced with irrigation and it was not affected by intercropping. Similar trend to that of the number of pods per plant was also observed for the length of pods, as there was 11 to $14 \%$ increase at the Isard monocrop, and its intercrops, under irrigation (Table 2). On the other hand, the number of grains per pod was not significantly affected by the irrigation treatment. 
Table 2. Yield components number of grains per pod, number of grains per spike, length of pod and spike of the different intercropping treatments that there were used under Irrigated and Rainfed conditions. Data presented are mean values with the least significant difference (LSD).

\begin{tabular}{|c|c|c|c|c|c|c|c|c|}
\hline \multirow[t]{3}{*}{ Treatments } & \multicolumn{2}{|c|}{ Number of Grains per Spike } & \multicolumn{2}{|c|}{ Number of Grains per Pod } & \multicolumn{2}{|c|}{ Length of Spike } & \multicolumn{2}{|c|}{ Length of Pod } \\
\hline & \multicolumn{2}{|c|}{ Wheat } & \multicolumn{2}{|c|}{ Pea } & \multicolumn{2}{|c|}{ Wheat } & \multicolumn{2}{|c|}{ Pea } \\
\hline & Irrigated & Rainfed & Irrigated & Rainfed & Irrigated & Rainfed & Irrigated & Rainfed \\
\hline Yecora E & 36.3 & 30.3 & - & - & 10.35 & 9.83 & - & - \\
\hline Elissavet & 46.9 & 45.5 & - & - & 9.75 & 10.17 & - & - \\
\hline Isard & - & - & 5.43 & 4.53 & - & - & 5.68 & 4.87 \\
\hline Olympos & - & - & 4.85 & 5.00 & - & - & 4.65 & 4.72 \\
\hline $\begin{array}{l}\text { Yecora } \\
\text { E-Isard }\end{array}$ & 43.9 & 30.5 & 4.77 & 4.57 & 11.98 & 12.00 & 5.47 & 4.75 \\
\hline $\begin{array}{c}\text { Yecora } \\
\text { E-Olympos }\end{array}$ & 38.9 & 31.3 & 4.92 & 5.05 & 11.58 & 11.55 & 4.42 & 4.92 \\
\hline $\begin{array}{l}\text { Elissavet- } \\
\text { Isard }\end{array}$ & 53.4 & 42.6 & 5.08 & 4.30 & 10.27 & 10.20 & 5.37 & 4.75 \\
\hline $\begin{array}{l}\text { Elissavet- } \\
\text { Olympos }\end{array}$ & 45.8 & 43.1 & 4.65 & 5.55 & 9.83 & 10.27 & 4.45 & 4.82 \\
\hline LSD & \multicolumn{2}{|c|}{10.05} & \multicolumn{2}{|c|}{0.95} & \multicolumn{2}{|c|}{1.01} & \multicolumn{2}{|c|}{0.55} \\
\hline
\end{tabular}

\subsection{Chlorophyll Content and Chlorophyll Fluorescence}

Chlorophyll content readings were not affected by the irrigation treatment but there were differences between the two species that were tested (Table 3). Similarly, quantum yield efficiency of photosystem (PS) II was not significantly affected by the intercropping and irrigation treatments but were observed differences among pea and wheat cultivars.

Table 3. Chlorophyll content and quantum yield efficiency (chlorophyll fluorescence) of the different intercropping treatments that there were used under Irrigated and Rainfed conditions. Data presented are mean values with the least significant difference (LSD).

\begin{tabular}{|c|c|c|c|c|c|c|c|c|}
\hline \multirow[t]{3}{*}{ Treatments } & \multicolumn{4}{|c|}{ Chlorophyll Content } & \multicolumn{4}{|c|}{ Quantum Yield (Chlorophyll Fluorescence) } \\
\hline & \multicolumn{2}{|c|}{ Wheat } & \multicolumn{2}{|c|}{ Pea } & \multicolumn{2}{|c|}{ Wheat } & \multicolumn{2}{|c|}{ Pea } \\
\hline & Irrigated & Rainfed & Irrigated & Rainfed & Irrigated & Rainfed & Irrigated & Rainfed \\
\hline Yecora E & 46.4 & 48.4 & - & - & 0.66 & 0.65 & - & - \\
\hline Elissavet & 48.6 & 50.0 & - & - & 0.67 & 0.65 & - & - \\
\hline Isard & - & - & 43.9 & 45.7 & - & - & 0.64 & 0.66 \\
\hline Olympos & - & - & 43.1 & 43.7 & - & - & 0.67 & 0.66 \\
\hline $\begin{array}{l}\text { Yecora } \\
\text { E-Isard }\end{array}$ & 48.9 & 50.4 & 44.9 & 47.2 & 0.65 & 0.67 & 0.61 & 0.65 \\
\hline $\begin{array}{c}\text { Yecora } \\
\text { E-Olympos }\end{array}$ & 49.0 & 49.9 & 42.5 & 44.1 & 0.65 & 0.63 & 0.66 & 0.63 \\
\hline $\begin{array}{l}\text { Elissavet- } \\
\text { Isard }\end{array}$ & 49.6 & 51.3 & 43.6 & 45.6 & 0.62 & 0.63 & 0.64 & 0.63 \\
\hline $\begin{array}{l}\text { Elissavet- } \\
\text { Olympos }\end{array}$ & 48.9 & 51.1 & 44.6 & 44.2 & 0.65 & 0.65 & 0.62 & 0.63 \\
\hline LSD & \multicolumn{2}{|c|}{2.06} & \multicolumn{2}{|c|}{2.48} & \multicolumn{2}{|c|}{0.037} & \multicolumn{2}{|c|}{0.052} \\
\hline
\end{tabular}

\subsection{Land Equivalent Ratio (LER)}

In most mixtures, the partial land equivalent ratio of wheat was lower than 0.5 (mean $\mathrm{LER}_{\mathrm{w}}=0.37-044$ ), while the $\mathrm{LER}_{\mathrm{p}}$ was higher than 0.5 (mean $\mathrm{LER}_{\mathrm{p}}=0.72-0.73$ ), with the exception of Yecora E-Isard rainfed mixture (0.43) (Table 4). The LER $\mathrm{w}_{\mathrm{w}}$ was $19 \%$ higher at irrigated treatments $(0.44)$ compared with the rainfed treatment $(0.37)$, whereas there was no significant difference in mean $\mathrm{LER}_{\mathrm{p}}$ values among irrigation treatments. In addition, among peas, cultivar Isard intercropped with Yecora E, had the lowest $L_{E R}$ values in both 
irrigation treatments. On the other hand, Yecora E intercropped with pea cultivar Isard was the most competitive wheat cultivar at both irrigation treatments $\left(\mathrm{LER}_{\mathrm{w}}=0.52-0.67\right)$.

Table 4. Land equivalent ratio (LER) of the different treatments that there were used under Irrigated and Rainfed conditions. Data presented are mean values with the least significant difference (LSD).

\begin{tabular}{|c|c|c|c|c|c|c|}
\hline \multirow[t]{3}{*}{ Treatments } & \multicolumn{4}{|c|}{ Partial Land Equivalent Ratio } & \multirow{2}{*}{\multicolumn{2}{|c|}{$\begin{array}{c}\text { Land Equivalent Ratio (LER) } \\
\text { Total }\end{array}$}} \\
\hline & \multicolumn{2}{|c|}{ Wheat $\left(\mathrm{LER}_{\mathrm{w}}\right)$} & \multicolumn{2}{|c|}{ Pea $\left(\right.$ LER $\left._{\mathrm{p}}\right)$} & & \\
\hline & Irrigated & Rainfed & Irrigated & Rainfed & Irrigated & Rainfed \\
\hline Yecora E-Isard & 0.67 & 0.52 & 0.55 & 0.43 & 1.22 & 0.95 \\
\hline $\begin{array}{c}\text { Yecora } \\
\text { E-Olympos }\end{array}$ & 0.35 & 0.31 & 0.87 & 0.88 & 1.22 & 1.19 \\
\hline Elissavet-Isard & 0.52 & 0.39 & 0.68 & 0.85 & 1.20 & 1.24 \\
\hline $\begin{array}{l}\text { Elissavet- } \\
\text { Olympos }\end{array}$ & 0.21 & 0.24 & 0.79 & 0.76 & 1.00 & 1.00 \\
\hline Mean & 0.44 & 0.37 & 0.72 & 0.73 & 1.16 & 1.10 \\
\hline LSD & \multicolumn{2}{|c|}{0.06} & \multicolumn{2}{|c|}{0.11} & \multicolumn{2}{|c|}{0.15} \\
\hline
\end{tabular}

A graphical representation of the interactions between pea and wheat cultivars is shown in Figure 4, where the left upper quadrant corresponds to situations in which pea cultivars suppressed wheat cultivars, which was shown in most mixtures, while the reverse is true in the bottom right quadrant (e.g., Isard-Yecora E mixture under rainfed conditions). The upper right quadrant corresponds to situation when there is facilitation between the two species higher growth, and this was shown in the Isard-Elissavet and Isard-Yecora E mixtures under irrigated conditions.

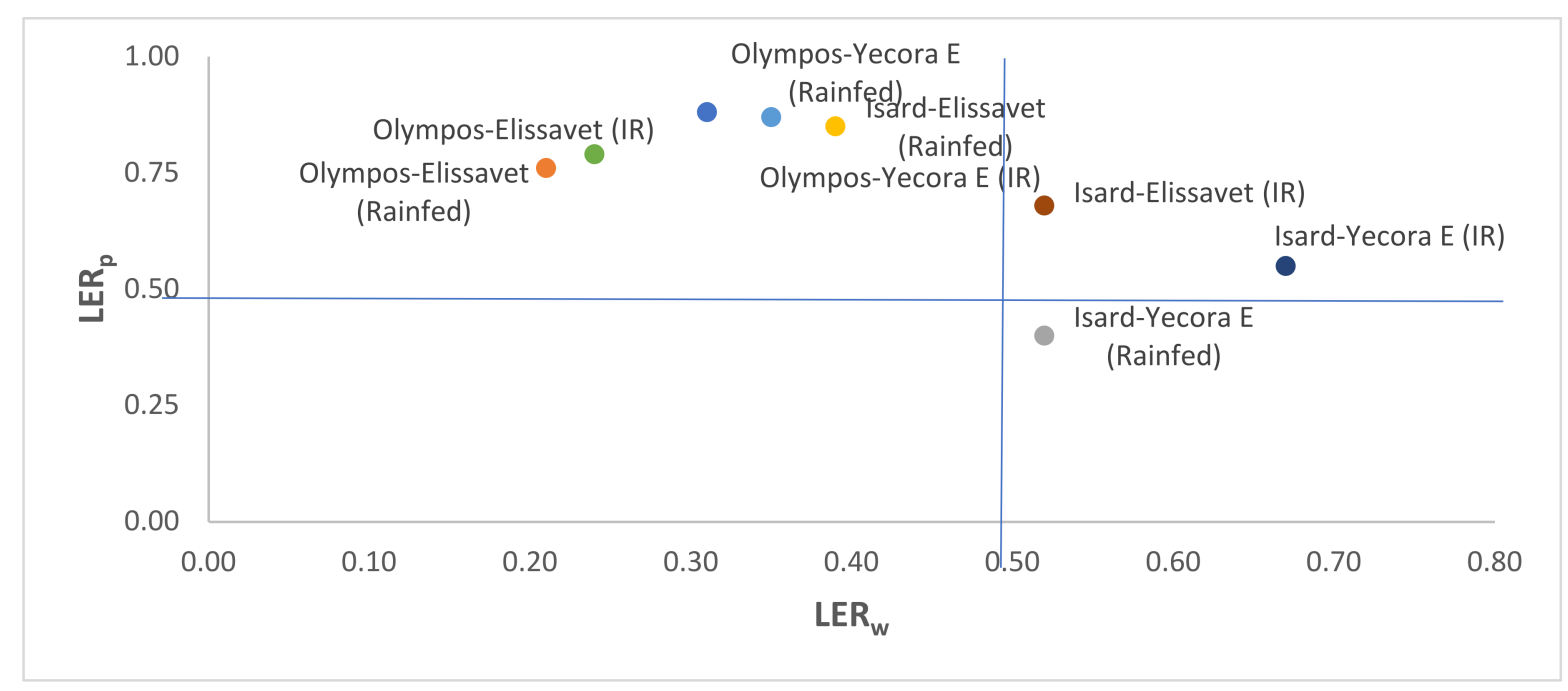

Figure 4. Partial LER values of the different intercropping systems that were used under rainfed conditions and also under irrigated.

In all mixtures, total LER was higher or equal to 1 (Table 4). In particular, at the irrigated treatment most mixtures had total LER significantly higher to $1(1.20-1.22)$ with the exception of Elissavet-Olympos mixture (1.00), whereas under rainfed treatment the highest total LER had the Elissavet-Isard (1.24) and Yecora E-Olympos (1.19) mixtures. Further, in Yecora E-Isard irrigated, total LER increased by $28 \%$ as compared with rainfed treatment.

\subsection{Water Use Efficiency}

In most cases, the WUE was not significantly affected by the irrigation, with the exceptions at the Isard monocrop and Yecora E-Isard intercrop as they were higher by 22 and $28 \%$, respectively, at the irrigated treatment compared with the rainfed treatments 
(Figure 5). In addition, WUE was higher in wheat cultivars as compared to pea cultivars, whereas pea Olympos had the lowest WUE.

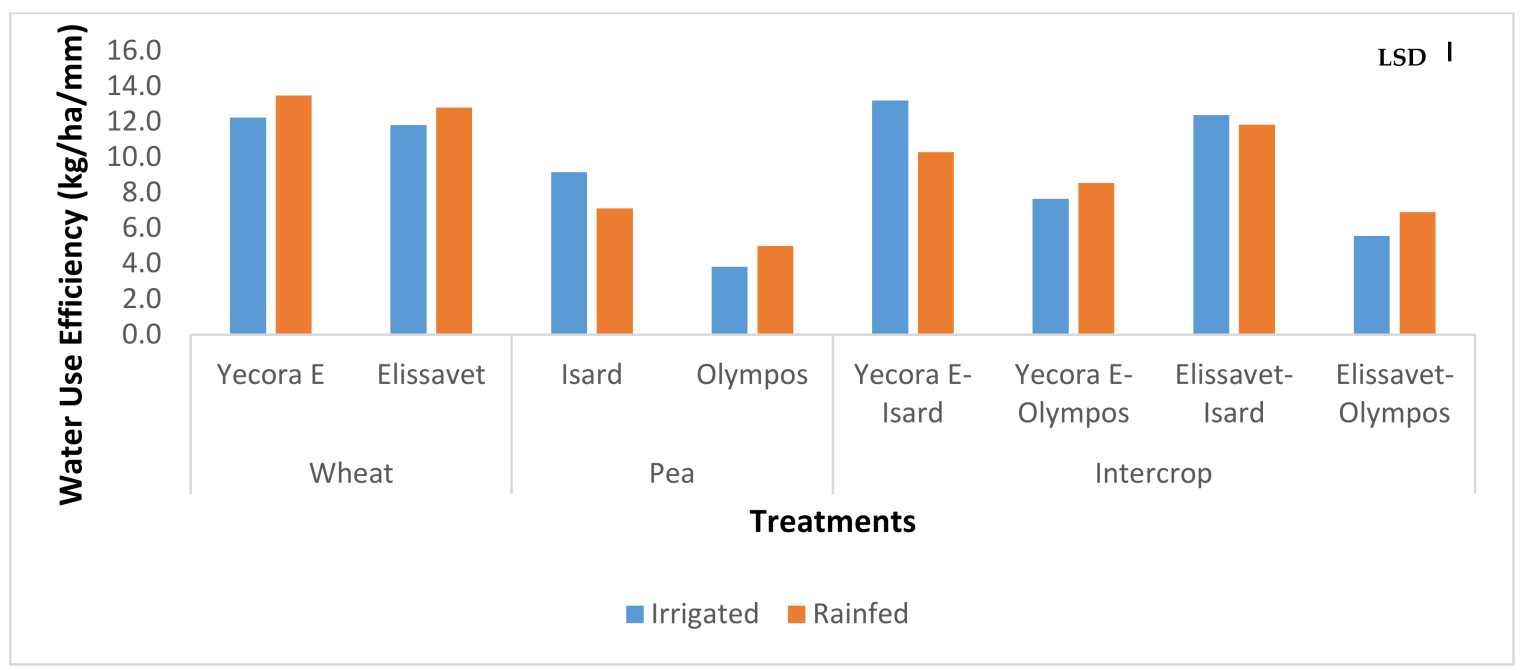

Figure 5. Water use efficiency of the different mixtures, monocrop under rainfed and irrigated conditions. Data presented are mean values; vertical bar corresponds to the least significant difference (LSD).

\section{Discussion}

\subsection{Grain Yield}

Under irrigated conditions, the greatest grain yield was obtained in two intercropping treatments (the mixtures of Isard with Yecora E and with Elissavet) and in the monocrops of both wheat cultivars, whereas both mixtures of Olympos with wheat showed the lowest yields (Figure 1). In other studies, it was reported that yield of intercropping systems (faba bean-cereal, pea-cereal, common vetch-cereal) was as high as the cereal monocrops [13,21-24]. In addition, there are several studies which show that mixtures of grain legumes with cereals produced more forage yield than grain legume and cereal monocrops because of better utilization of the environmental resources [14,25-27]. There were significant differences between the two pea cultivars and their mixtures, as well as the highest grain yield were found at Isard and its mixtures. This is possible because the cultivar Isard is for grain yield and Olympos is for biomass production and is used for forage production and animal feed $[27,28]$. In addition, Olympos has indeterminate growth whereas Isard has a determinate growth and this means that Olympos continued to grow and produce more flowers and there was not enough time for the grains to grow and complete its development [29].

Under rainfed conditions, the highest grain yield was found at the wheat monocrops and followed by the Elissavet-Isard mixture, indicating better adaptability of wheat cultivars to dryland conditions [15]. In addition, Isard monocrop and Isard-wheat intercrops were affected more by the irrigation treatments as the grain yield were reduced by 28 to $34 \%$ under rainfed conditions compared with the irrigated treatments (Figure 2). In contrast, grain yield of Olympos monocrop was not significantly affected by the water stress conditions and this trend was also found in the mixtures of Olympos with the two wheat cultivars, indicating that it is well adapted in the Mediterranean conditions compared with Isard which was affected by the irrigation treatment and showed a significant increase with irrigation. This is probably because Olympos was bred under dry land conditions in a Mediterranean environment and Isard was bred under a more humid environment.

\subsection{Yield Components}

Yield components of grain legumes and cereals can be affected by fertilization, plant density, source-sink relationships, genotype, and environmental factors (e.g., drought, salinity) [30-32]. In our work, the yield components of wheat monocrops were not affected 
by irrigation (Figure 2; Table 2), although were reported that most of the yield components (i.e., number of spikes per plant, number of grains per spike, weight of grains per spike, etc.) were affected by irrigation [26]. On the contrary, in most intercrops, irrigation affected the number of spikes per plant and the number of grains per spike, as there was an increase with irrigation compared with the rainfed treatment, probably because of competitive ability of wheat intercropped under optimum conditions [13-15]. In addition, irrigation could affect the grain development and the yield components as it could be affected by the photo assimilates distribution in the plant [26,33-35]. Irrigation affected more the yield components of pea cultivar Isard monocrop and its intercrops that seemed to be more responsive to irrigation and more sensitive to water stress compared with the cultivar Olympos, probably because of the better adaptability of Olympos in Mediterranean conditions.

\subsection{Chlorophyll Content and Chlorophyll Fluorescence}

Chlorophyll meters have been used extensively in agriculture to determine the $\mathrm{N}$ status of the crop and also to determine the degree of greenness of the leaves, which is important for high yield. It was also used from different studies as a good indicator of green color and the stay green characteristic in several plant species and as a stress tolerance index [32]. Chlorophyll fluorescence and especially the maximum quantum efficiency of PSII photochemistry was used as a stress indicator in several species for water stress [36,37]. In the present study there was no significant effect of irrigation or/and of the intercropping treatments, but only of the different species, on chlorophyll content and chlorophyll fluorescence. Similar values for wheat and pea of quantum yield efficiency were reported by others $[14,15,37]$ but it was not determined under stress conditions and under intercropping treatments. In other plant species it was found that chlorophyll content can be used to indicate the tolerant cultivars to water stress [36,37]. However, our results indicate that chlorophyll meter readings or/and chlorophyll fluorescence cannot be used as selection criteria for tolerant cultivars to water stress.

\subsection{Land Equivalent Ratio (LER)}

Land Equivalent ratio was used extensively in intercropping systems to evaluate its productivity $[4,6]$. In most mixtures, the partial LER of wheat was lower than 0.5 , while the partial LER of pea was higher than 0.5 , which indicates that there was an advantage for pea in these intercropping systems and a disadvantage for wheat [18]. Similarly, bivariate diagrams illustrated suppression ability of wheat cultivars (most of partial LER pea $_{\text {values }}$ in left upper quadrant), which confirmed the competitive ability of peas [38,39].

Among peas, cultivar Isard intercropped with Yecora E, had the lowest $L_{E R}$ values in both irrigation treatments, indicating that pea Isard in this intercrop had lower competitive ability than peas in other mixtures. On the other hand, the $\mathrm{LER}_{\mathrm{w}}$ was higher by $19 \%$ at irrigated treatments compared with the rainfed treatments, seemed that wheats to be more favored under irrigation. The observed decrease of $\mathrm{LER}_{\mathrm{p}}$ values in some of the mixtures could be attributed to the stronger competitive nature of one species over the other and this can be more pronounced under stressful conditions like the rainfed conditions that existed in the present study [18,39].

The total LER is used to determine the efficiency of intercropping for using the environmental resources compared with monocrops. In our study, there was a yield advantage of intercrops over monocrops as total LER was higher or equal to 1 for all intercrops. More specifically, the greatest LER in the cases of Elissavet-Isard (1.24) and Yecora E-Olympos (1.19) rainfed, as well as Yecora E-Isard (1.22), Yecora E-Olympos (1.22) and Elissavet-Isard (1.20) irrigated indicates that up to $19-24 \%$ more land area would be required of monocropping system to equal the yield of intercropping system [14,18,27]. These results suggest that intercropping remains beneficial, both under stressful and nonstressful contexts concerning moisture availability. In these cases, the significant yield advantage of intercrops over monocrops can be because of the better land utilization and the better use of the environmental resources for plant growth because of their better 
arrangement $[14,40]$. Similarly, intercropping advantages were reported in mixtures with different grain legumes such as common vetch, faba bean, and pea and different winter cereals $[13,30,40]$. On the other hand, in both Elissavet-Olympos intercrops and in Yecora E-Isard rainfed the LER values were close to unit, which indicates that there was no yield advantage or disadvantage over monocrops $[13,14]$.

\subsection{Water Use Efficiency}

The WUE was significantly affected by the irrigation level only at the Isard monocrop and Yecora E-Isard intercrop as they were higher by 22 and 28\%, respectively, at the irrigated treatment compared with the rainfed treatments. In addition, the WUE that was found was much higher than in other species such as cotton, maize, and this is because the higher productivity and better adaptability of the wheat cultivars [9,12].

In most cases, the WUE was not significantly affected by the irrigation. The fact that under rainfed conditions wheat cultivars and the pea cultivar Olympos did not show reduction in WUE indicates that these cultivars utilize the available water more efficiently. This is very important as when there is limited water supply it is better to find tolerant to water stress cultivars which can efficiently use water and produce a good yield [10,11].

\section{Conclusions}

Pea-wheat intercropping was used across the world for forage and grain production. In the present study we showed that intercropping can be affected by water availability and also by the selection of the appropriate cultivar which can affect the productivity of the intercropping system and also WUE. The grain yield was higher in Isard-Yecora E and Isard-Elissavet irrigated intercrops compared with the monocrops and other intercrops. In terms of total LER there was a yield advantage of most intercrops over monocrops, which indicates the efficiency of intercropping for using the environmental resources. In addition, Yecora E-Isard mixtures showed a significant increase in WUE and this can be achieved by the selection of appropriate cultivars that can be used in intercropping systems and can be used to conserve water resources, especially in areas with limited water resources for irrigation. Under rainfed conditions, both wheat cultivars, Olympos pea and their intercrops indicated high adaptation capacity to less water availability, whereas Isard and its intercrops performed better under irrigation. These results suggest that intercropping remains beneficial, both under stressful and non-stressful contexts concerning moisture availability. Therefore, they can be used by the farmers in Mediterranean areas as they are the most profitable systems.

Author Contributions: All the authors have contributed on the manuscript significantly. C.P. conducted the experiments. A.L. designed and took care of the experiments. C.D. was responsible for conducting the experiment and also writing the manuscript. All authors have read and agreed to the published version of the manuscript.

Funding: This work has been supported by ReMIX—project which has received funding from the European Union's Horizon 2020 Programme for Research \& Innovation under grant agreement $\mathrm{n}^{\circ} 727217$.

Data Availability Statement: The data presented in this study are available on request from the corresponding author. The data are not publicly available due to privacy restrictions.

Acknowledgments: We are grateful to the personnel of the University Farm of the Aristotle University of Thessaloniki for assistance with the field experiments. Moreover, to George Menexes for assistance of the statistical analysis.

Conflicts of Interest: The authors declare no conflict of interest. 


\section{References}

1. Altieri, M.A. The ecological role of biodiversity in agroecosystems. Agron. Ecosyst. Environ. 1999, 74, 19-31. [CrossRef]

2. Malézieux, E.; Crozat, Y.; Dupraz, C.; Laurans, M.; Makowski, D.; Ozier-Lafontaine, H.; Rapidel, B.; de Tourdonnet, S.; ValantinMorison, M. Mixing plant species in cropping systems: Concepts, tools and models. A review. Agron. Sustain. Dev. 2009, 29, 43-62. [CrossRef]

3. Stomph, T.; Dordas, C.; Baranger, A.; Bedoussac, L.; de Rijk, J.; Dong, B.; Evers, J.; Gu, C.; Li, L.; Simon, J.; et al. Designing intercrops for high yield, yield stability and efficient use of resources: Are there principles? Adv. Agron. 2020, 160, 1-50.

4. Bedoussac, L.; Journet, E.-P.; Hauggaard-Nielsen, H.; Naudin, C.; Corre-Hellou, G.; Jensen, E.S.; Prieur, L.; Justes, E. Ecological principles underlying the increase of productivity achieved by cereal-grain legume intercrops in organic farming. A review. Agron. Sustain. Dev. 2015, 35, 911-935. [CrossRef]

5. Brooker, R.W.; Bennett, A.E.; Cong, W.-F.; Daniell, T.J.; George, T.S.; Hallett, P.D.; Hawes, C.; Iannetta, P.P.M.; Jones, H.G.; Karley, A.J.; et al. Improving intercropping: A synthesis of research in agronomy, plant physiology and ecology. New Phytol. 2015, 206, 107-117. [CrossRef] [PubMed]

6. Lithourgidis, A.S.; Dordas, C.A.; Damalas, C.A.; Vlachostergios, D.N. Annual intercrops: An alternative pathway for sustainable agriculture. Aust. J. Crop Sci. 2011, 5, 396-410.

7. Bedoussac, L.; Journet, E.-P.; Hauggaard-Nielsen, H.; Naudin, C.; Corre-Hellou, G.; Jensen, E.S.; Justes, E. Grain legume-cereal intercropping systems. In Achieving Sustainable Cultivation of Grain Legumes Volume 1: Advances in Breeding and Cultivation Techniques; Sivasankar, S., Ed.; Burleigh Dodds Science Publishing: Cambridge, UK, 2018.

8. Inal, A.; Gunes, A.; Zhang, F.; Cakmak, I. Peanut/maize intercropping induced changes in rhizosphere and nutrient concentrations in shoots. Plant Physiol. Biochem. 2007, 45, 350-356. [CrossRef] [PubMed]

9. Blum, A. Plant Breeding for Water-Limited Environment; Springer: New York, NY, USA, 2011; ISBN 978-1-4419-7490-7. [CrossRef]

10. Chen, G.X.; Kong, Y.; Gan, R.; Zhang, F.; Feng, A.; Yu, C.; Zhao, S.; Wan, Q. Chai Enhancing the systems productivity and water use efficiency through coordinated soil water sharing and compensation in strip intercropping. Sci. Rep. 2018, 8, 10494. [CrossRef]

11. Fan, Z.; Chai, Q.; Huang, G.; Yu, A.; Huang, P.; Yang, C.; Tao, Z.; Liu, H. Yield and water consumption characteristics of wheat/maize intercropping with reduced tillage in an Oasis region. Eur. J. Agron. 2013, 45, 52-58. [CrossRef]

12. Yang, C.; Huang, G.; Chai, Q.; Luo, Z. Water use and yield of wheat/maize intercropping under alternate irrigation in the oasis field of northwest China. Field Crops Res. 2011, 124, 426-432. [CrossRef]

13. Dordas, C.A.; Vlachostergios, D.N.; Lithourgidis, A.S. Growth dynamics and agronomic-economic benefits of pea-oat and pea-barley intercrops. Crop Pasture Sci. 2012, 63, 45-52. [CrossRef]

14. Lithourgidis, A.S.; Vlachostergios, D.N.; Dordas, C.A.; Damalas, C.A. Dry matter yield, nitrogen content, and competition in pea-cereal intercropping systems. Eur. J. Agron. 2011, 34, 287-294. [CrossRef]

15. Lithourgidis, A.S.; Dordas, C.A. Forage yield, growth rate, and nitrogen uptake of faba bean intercrops with wheat, barley, and rye in three seeding ratios. Crop Sci. 2010, 50, 2148-2158. [CrossRef]

16. Kalamartzis, I.; Dordas, C.; Georgiou, P.; Menexes, G. The Use of Appropriate Cultivar of Basil (Ocimum basilicum) Can Increase Water Use Efficiency under Water Stress. Agronomy 2020, 10, 70. [CrossRef]

17. Howell, T.A. Enhancing water use efficiency in irrigated agriculture. Agron. J. 2001, 93, 281-289. [CrossRef]

18. Mead, R.; Willey, R.W. The concept of a 'land equivalent ratio' and advantages in yields from intercropping. Exp. Agric. 1980, 16, 217-228. [CrossRef]

19. Dhima, K.V.; Lithourgidis, A.S.; Vasilakoglou, I.B.; Dordas, C.A. Competition indices of common vetch and cereal intercrops in two seeding ratio. Field Crops Res. 2007, 100, 249-256. [CrossRef]

20. Steel, R.G.D.; Torrie, J.H.; Dickey, D.A. Principles and Procedures of Statistics: A Biometrical Approach, 2nd ed.; McGraw-Hill: New York, NY, USA, 1997.

21. Berkenkamp, B.; Meeres, J. Mixtures of annual crops for forage in central Alberta. Can. J. Plant Sci. 1987, 67, 175-183. [CrossRef]

22. Lithourgidis, A.S.; Vasilakoglou, I.B.; Dhima, K.V.; Dordas, C.A.; Yiakoulaki, M.D. Forage yield and quality of common vetch mixtures with oat and triticale in two seeding ratios. Field Crops Res. 2006, 99, 106-113. [CrossRef]

23. Carr, P.M.; Horsley, R.D.; Poland, W.W. Barley, oat, and cereal-pea mixtures as dryland forages in the northern Great Plains. Agron. J. 2004, 96, 677-684. [CrossRef]

24. Agegnehu, G.; Ghizaw, A.; Sinebo, W. Yield potential and land-use efficiency of wheat and faba bean mixed intercropping. Agron. Sustain. Dev. 2008, 28, 257-263. [CrossRef]

25. Lithourgidis, A.S.; Dhima, K.V.; Vasilakoglou, I.B.; Dordas, C.A.; Yiakoulaki, M.D. Sustainable production of barley and wheat by intercropping common vetch. Agron. Sustain. Dev. 2007, 27, 95-99. [CrossRef]

26. Singh, B.; Aulakh, C.S.; Walia, S.S. Productivity and water use of organic wheat-chickpea intercropping system under limited moisture conditions in northwest India. Renew. Agric. Food Syst. 2019, 34, 134-143. [CrossRef]

27. Baxevanos, D.; Tsialtas, I.T.; Vlachostergios, D.N.; Hadjigeorgiou, I.; Dordas, C.; Lithourgidis, A. Cultivar competitiveness in pea-oat intercrops under Mediterranean conditions. Field Crops Res. 2017, 214, 94-103. [CrossRef]

28. Tsialtas, I.T.; Baxevanos, D.; Vlachostergios, D.N.; Dordas, C.; Lithourgidis, A. Cultivar complementarity for symbiotic nitrogen fixation and water use efficiency in pea-oat intercrops and its effect on forage yield and quality. Field Crops Res. 2018, $226,28-37$. [CrossRef] 
29. Mamine, F.; Farès, M. Barriers and Levers to Developing Wheat-Pea Intercropping in Europe: A Review. Sustainability 2020, 12, 6962. [CrossRef]

30. Dordas, C.A. Variation in dry matter and nitrogen accumulation and remobilization in barley as affected by fertilization, cultivar, and source-sink relations. Eur. J. Agron. 2012, 37, 31-42. [CrossRef]

31. Haby, V.A.; Black, A.L.; Bergman, J.W.; Larson, R.A. Nitrogen Fertilizer Requirements of Irrigated Safflower in the Northern Great Plains 1. Agron. J. 1982, 74, 331-335. [CrossRef]

32. Dordas, C.; Papathanasiou, F.; Lithourgidis, A.; Petrevska, J.K.; Papadopoulos, I.; Pankou, C.; Gekas, F.; Ninou, E.; Mylonas, I.; Sistanis, I.; et al. Evaluation of physiological characteristics as selection criteria for drought tolerance in maize inbred lines and their hybrids. Maydica 2018, 63, 1-14.

33. Ciompi, S.; Gentili, E.; Guidi, L.; Soldatini, G.F. The effect of nitrogen deficiency on leaf gas exchange and chlorophyll fluorescence parameters in sunflower. Plant Sci. 1996, 118, 177-184. [CrossRef]

34. Cechin, I.; Fumis, T.F. Effect of nitrogen supply on growth and photosynthesis of sunflower plants grown in the greenhouse. Plant Sci. 2004, 166, 1379-1385. [CrossRef]

35. Zhao, D.; Reddy, R.K.; Kakani, V.G.; Reddy, V.R. Nitrogen deficiency effects on plant growth, leaf photosynthesis, and hypespectral reflectance properties of sorghum. Eur. J. Agron. 2005, 22, 391-403. [CrossRef]

36. Al-Ghzawi, A.L.A.; Khalaf, Y.B.; Al-Ajlouni, Z.I.; AL-Quraan, N.A.; Musallam, I.; Hani, N.B. The Effect of Supplemental Irrigation on Canopy Temperature Depression, Chlorophyll Content, and Water Use Efficiency in Three Wheat (Triticum aestivum L. and T. durum Desf.) Varieties Grown in Dry Regions of Jordan. Agriculture 2018, 8, 67. [CrossRef]

37. Botyanszka, L.; Zivcak, M.; Chovancek, E.; Sytar, O.; Barek, V.; Hauptvogel, P.; Halabuk, A.; Brestic, M. Chlorophyll Fluorescence Kinetics May Be Useful to Identify Early Drought and Irrigation Effects on Photosynthetic Apparatus in Field-Grown Wheat. Agronomy 2020, 10, 1275. [CrossRef]

38. Bedoussac, L.; Justes, E. A comparison of commonly used indices for evaluating species interactions and intercrop efficiency: Application to durum wheat-winter pea intercrops. Field Crops Res. 2011, 124, 25-36. [CrossRef]

39. Helenius, J.; Jokinen, K. Yield advantage and competition in intercropped oats (Avena sativa L.) and faba bean (Vicia faba L.): Application of the hyperbolic yield-density model. Field Crops Res. 1994, 37, 85-94. [CrossRef]

40. Agegnehu, G.; Ghizaw, A.; Sinebo, W. Yield performance and land-use efficiency of barley and faba bean mixed cropping in Ethiopian highlands. Eur. J. Agron. 2006, 25, 202-207. [CrossRef] 